\title{
Candidate Selection, Personalization and Different Logics of Centralization in New Southern European Populism: The Cases of Podemos and the M5S
}

\author{
Manuela Caiani $^{1 \star}$ (D), Enrico Padoan ${ }^{2}$ (D) and Bruno Marino 3 (D) \\ ${ }^{1}$ Faculty of Social and Political Sciences, Scuola Normale Superiore, Florence, Italy, ${ }^{2}$ Faculty of Social and \\ Political Sciences, Scuola Normale Superiore, Florence, Italy, and ${ }^{3}$ Department of Political and Social \\ Sciences, University of Bologna, Bologna, Italy \\ ${ }^{*}$ Corresponding author. Email: manuela.caiani@sns.it
}

(Received 7 April 2020; revised 7 February 2021; accepted 12 February 2021;

first published online 8 April 2021)

\begin{abstract}
In this article, we focus on the candidate selection processes of Podemos in Spain and the Movimento 5 Stelle (M5S - Five Star Movement) in Italy, processes which are related to intra-party democracy. With a mixed-methods approach (including novel data from the expert survey PoPES, 31 semi-structured interviews with party representatives and militants, and analysis of party documents, statutes and leader speeches) and a comparative perspective, we explore candidate selection in the context of the broader organizational party structures over time. We find that: (1) Podemos functions like a typical centralized party, whereas M5S is a deviant case with strong and centralized control over party organization but decentralized mechanisms for candidate selection; (2) both these logics of centralization of power undermine the parties' democratic credentials but have different consequences in terms of cohesion (expulsions/departures in M5S and splintering in Podemos); and (3) in both cases, the parties' organizational culture and symbolic tools legitimate their top-down features.
\end{abstract}

Keywords: candidate selection; personalization of politics; intra-party democracy (IPD); Southern European populism; centralization of power; interviews with militants and representatives

Although two areas of recent academic interest, Southern European populist (sometimes 'inclusionary') ${ }^{1}$ parties and the personalization of politics, are deeply related, analyses that explicitly link them are scarce. Numerous publications analyse the organizational characteristics and evolution of Podemos in Spain (e.g. Chironi and Fittipaldi 2017; Martín 2015; Sola and Rendueles 2017) and the Italian Five Star Movement (M5S) (e.g. Biorcio and Natale 2018; Bordignon and Ceccarini

(C) The Author(s), 2021. Published by Cambridge University Press on behalf of Government and Opposition Limited. This is an Open Access article, distributed under the terms of the Creative Commons Attribution licence (http://creativecommons.org/licenses/by/4.0/), which permits unrestricted re-use, distribution, and reproduction in any medium, provided the original work is properly cited. 
2015; Corbetta and Gualmini 2013; Vignati 2015a, 2015b) individually and in comparative perspective (e.g. della Porta et al. 2017; Ivaldi et al. 2017; Mikola 2017; Vittori 2017). Other studies focus more precisely on their intra-party democracy (IPD) (Mikola 2017; Vittori 2019), emphasizing the (negative) impact of online platforms (Deseriis and Vittori 2019; Gerbaudo 2018, 2019); but none focuses specifically on candidate selection and the personalization of politics.

Taken together, these studies conclude that both Podemos and the M5S are extremely centralized and have poor levels of internal democracy. Although Podemos is sometimes categorized as a 'movement party' (Chironi and Fittipaldi 2017; della Porta et al. 2017; Vittori 2017) because of its origins in the Indignados movement (Sola and Rendueles 2017), the robust role of its activists (Martín 2015) and its participative ethos (Gerbaudo 2019), Pablo Iglesias's leadership and power (since the party's foundation) are largely considered central, undeniable and almost unchallengeable (Mikola 2017). Similarly, the Five Star Movement was also inspired by a leaderless and anti-establishment movement, but the literature (Ceri and Veltri 2017; Lanzone 2015) emphasizes the strict control wielded by the party's two founders, Beppe Grillo and Gianroberto Casaleggio, both in the 'party in public office' and 'on the ground' (Katz and Mair 1993).

Despite growing interest in the personalization of politics (Correa et al. 2018), few studies aim to understand the personalization of politics in Southern European populist parties, and the relationship between candidate selection processes and broader organizational features is equally under-studied. But as E.E. Schattschneider (1942: 64) stressed more than 70 years ago, candidate selection is 'one of the best points at which to observe the distribution of power within the party'. In fact, just a few studies focus on the candidate selection processes in these parties (on Podemos, Pérez-Nievas et al. 2018; on the M5S, Seddone and Rombi 2018) and comparative research is rare (for exceptions, see Lanzone and Rombi 2018; Mikola 2019).

Moreover, the extant literature offers conflicting conclusions. Whereas some stress that candidate selection is (at least formally) a relatively inclusive process in both parties (Albertini 2019; Mikola 2017, 2019; Pérez-Nievas et al. 2018), others have doubts (mainly concerning the M5S) and claim it is 'hyper closed' (Lanzone and Rombi 2014; Seddone and Rombi 2018: 239). Most of these analyses 'do not capture the impact of informal pressure from the party leader on the outcome of primaries' (Mikola 2019: 103), ${ }^{2}$ an aspect that, we argue, is key to understanding how candidate selection works in practice (see also Pérez-Nievas et al. 2018).

This article is not about the personalization of politics (in 'digital' parties; Gerbaudo 2018) as such; instead, it focuses on a very specific aspect of IPD, namely the selection of candidates for elections in Podemos and the M5S. The topic is empirically, scientifically and normatively interesting for a number of reasons, including the contradiction between the parties' 'inclusionary' bent (Mudde and Rovira Kaltwasser 2013) and 'elitist' outcomes. By focusing on these two Southern European populist parties, we explore the formal and informal mechanisms of candidate selection (such as rules, procedures, and ideological and symbolic tools), locating them in their broader organizational and internal decision-making structures. The study draws on party documents, interviews with party representatives and militants (at the local and national levels), and a novel cross-party and 
cross-disciplinary expert survey. We explore the processes of candidate selection in comparative and longitudinal perspectives, problematizing the complex relationships between them and IPD. We pay close attention to the actors' perceived threats and opportunities and the consequences of different logics of centralization in the two parties.

In the theoretical and methodological sections, we define and operationalize our relevant concepts (such as personalization and candidate selection). We then use insights from the expert survey to identify the characteristics ('degree and forms', or configurations) of personalized politics in Podemos and the M5S. While Podemos appears to be a typical case of personalization in populism, the M5S emerges as a deviant case in the European context. In the subsequent two sections, our qualitative analysis and interviews shed light on the various organizational (formal and informal) aspects related to the candidate selection process, describing the mechanisms of the different configurations. Although both parties possess bottom-up provisions for candidate selection, their leaders have been able to maintain (and even increase) strict control over their respective organizations. However, two different logics of centralization have led to two different outcomes (in terms of IPD): expulsions in Italy and splintering in Spain. In the Conclusion we problematize how the organizational cultures of both parties have legitimized both processes, demonstrating tensions between their ideologies (both based on horizontality) and praxis (i.e. plebiscitarianism).

\section{Analytical framework: IPD, candidate selection and personalization of politics in populist parties}

The following review of key contributions from the literature on candidate selection and personalization of politics is not meant to be exhaustive, but rather sets out some analytical guidelines for this study. We bridge three strands of research: IPD, candidate selection and personalization and populism.

Party organizations and IPD are undergoing relevant changes, with political parties distancing themselves from society (Mair 2013) and undertaking a process of 'cartelization' (Katz and Mair 1995) and deep modifications in their IPD (Cross and Katz 2013; Ignazi 2018; Van Biezen and Poguntke 2014). Candidate selection is a crucial aspect of IPD (e.g. von dem Berge et al. 2013; Mikola 2017; Rahat and Shapira 2017 on populist parties). However, the relationship between candidate selection and IPD is highly contested. Varied - and sometimes contradictory - conclusions and empirical results regarding the causes and effects of different candidate selection processes ('open' v. 'closed') on IPD and personalization of politics abound. Some scholars (e.g. Katz and Mair 1995; Musella 2018) argue that a wide selectorate (i.e. those selecting the party candidates for general elections) lowers a party's IPD. They stress that broadening candidates' selectorate allows leaders to centralize and personalize their power at the expense of activists' influence. Others, however, claim that more open candidate selection rules foster 'decentralized personalization' (Balmas et al. 2014), giving representatives more power and autonomy than central leaders (Rahat and Hazan 2001). 
The concept of personalization of politics is also contested. Most definitions start from a common foundation: 'individual figures' are more important than 'structures' (Balmas et al. 2014; Karvonen 2010). But studies then diverge and focus on different aspects, such as the importance of party leaders to electoral campaigns and political parties or single candidates (personalities) to election results (e.g. Garzia 2011; Kriesi 2011; Rahat and Kenig 2018). In many studies, personalization is understood (explicitly or implicitly) as centralized personalization and treated as synonymous with centralization, or the empowerment of the party leader. However, some scholars suggest distinguishing between 'centralized' and 'decentralized' personalization: the former is when 'power flows upwards from the group (e.g. political party, cabinet) to a single leader (e.g. party leader, prime minister, president)' (Balmas et al. 2014: 37); the latter is the opposite, when 'power flows downwards from the group to individual politicians who are not party or executive leaders (e.g. candidates, members of parliament)' (Balmas et al. 2014: 37). In general personalization is linked to the centralization of power (within parties, cabinets, etc.; e.g. Blondel and Thiébault 2010; Musella 2015, 2018).

This entanglement between candidate selection and personalization is especially relevant in populist parties (Heinisch and Mazzoleni 2016) because their success is linked to the organizational and representational legitimation crises of traditional political parties (e.g. Kriesi 2014). These populist parties often declare that citizens need to reclaim sovereignty from party or national elites through candidate selection mechanisms (Albert and La Raja 2020) or other tools that foster members' participation in intra-party decisions (Gerbaudo 2019).

However, many new populist parties differ from their mainstream counterparts in their approaches to IPD, and they tend to become less democratic over time: as new parties grow electorally, their elites tend to take more control of the candidate selection process (Cordero et al. 2018).

A few scholars have looked specifically at candidate selection processes in new populist parties in Southern Europe. Maria Elisabetta Lanzone and Stefano Rombi (2018) and Bálint Mikola (2017), following Gideon Rahat and Reuven Hazan's (2001) framework, stress that the M5S is quite exclusive in terms of selectorate and candidacy (e.g. in 2013), in particular. Meanwhile, Santiago Pérez-Nievas et al. (2018) consider Podemos exclusive in terms of appointments and voting system.

Because candidate selection implies at least some degree of personalization, our question is not 'does personalization exist?'; rather, we aim to understand how candidate selection - and its inherent personalization - interacts with IPD. In other words, which method of candidate selection leads to more or less centralization and does that impact IPD positively or negatively?

We start from the following assumptions: (1) centralization and personalization are two distinct phenomena and should not be used interchangeably; (2) these two processes can occur simultaneously (Wauters et al. 2016) or independently, and this can generate different 'logics of centralization' or configurations of power; ${ }^{3}$ and (3) the expansion of the selectorate and the increase in IPD may or may not be related to the personalization of politics, but can depend on many factors (e.g. reactions to growing disaffection with political parties, exclusion from the state or political processes, etc.). 
We explore the candidate selection processes, intra-party organization and role of leadership in Podemos and M5S. We find that although they are both new populist parties, only Podemos conforms to the expected pattern; the M5S presents a deviant configuration. In the second part of the article, we discuss the conditions (i.e. mechanisms) under which this outcome emerges.

\section{Method, sources and operationalization}

This study is based on a combination of quantitative and qualitative data, including 31 semi-structured interviews with local and national representatives and militants of Podemos and M5S (for the list of interviewees, see List A in the Online Appendix) and novel data from the expert survey PoPES (Marino et al. 2018, 2020). ${ }^{4}$ The data set includes information on national elections from the mid-1980s until 2016 in 17 European countries and more than 100 parties (populist and non-populist). ${ }^{5}$

Since we are interested in exploring candidate selection processes in relation to broader organizational functions and the power of the parties' leader(s), we focus on four aspects related to personalization of politics and candidate selection: leader autonomy in candidate selection, ${ }^{6}$ leader control over the party organization, ${ }^{7}$ the general personalization of politics in elections in the country ${ }^{8}$ and autonomy of the leader in defining the policymaking agenda of the party. ${ }^{9}$

These four variables relate to two broad themes for analysis: the relationship between the leader(s) and party organization and the relationship between the leader(s) and elections. The leader/party organization relationship refers generally to the intra-party power of the leader. This category includes bottom-up v. top-down party origin, formal distribution of power within the party, parties' decision-making and agenda-setting procedures, and the like. The leader/elections relationship has to do with the rules and procedures (including leaders' autonomy) of candidate selection, longitudinal party consolidation trajectories and the symbolic or ideological tools for justifying these arrangements. These categories structure the sections that examine the two parties in turn.

We first explore these themes quantitatively, comparing our two cases with other European populist and mainstream parties in their respective countries; we then turn to qualitative investigation to better understand the mechanisms that enable the different configurations of power and leadership. We identify clusters of countries and parties that are highly centralized or personalized in some respects but not in others ${ }^{10}$ (see Figures A, B in the Online Appendix), and we find that populist parties tend to be more personalized than their non-populist counterparts. Candidate selection and personalization are therefore multifaceted phenomena that are worth exploring in greater depth.

The 31 semi-structured interviews were conducted face-to-face in Spain and Italy between September 2016 and December $2018 .{ }^{11}$ Our questions focused on parties' internal organizational procedures, functions (formal and informal) and processes of candidate selection and how interviewees' perceptions and opinions of the parties changed over time. We also systematically analysed party documents, such as statutes, manifestos, leaders' speeches, and internal organizational documents (e.g. the M5S Ethical Code 2017a, 2017b). For details about the sources, see List $\mathrm{B}$ in the Online Appendix. We paid attention to the concept of party 
culture (Freeman 1986), as it (and its creation) could justify and support parties' procedures. We used Rahat and Hazan's (2001; Hazan and Rahat 2010) four dimensions of candidate selection. ${ }^{12}$

Spain and Italy are two cases crucial to understanding candidate selection and leaders' power in populist parties. Beyond being examples of recent populist successes, candidate selection is strongly related to 'representational and policy outcomes' (Cross 2008) in these two countries in particular. Because of their electoral and party systems, it is extremely difficult for independent candidates to be elected. If we take Podemos and the M5S as representatives of the new wave of left-wing or hybrid parties that emerged in Southern Europe out of times of crisis, they have a great deal to teach us about the complex relationship between 'personal parties', populism and poor organizational resources. By analysing these parties' candidate selection processes, we hope to offer an empirical contribution that will further problematize the three above-mentioned aspects (namely candidate selection, leaders' power in populist parties and IPD), which may be co-causes of the multifaceted phenomenon of personalization. ${ }^{13}$

\section{Candidate selection and personalization of politics in Podemos and the M5S}

In Figure 1, we compare Podemos and the M5S to other Western European populist parties ${ }^{14}$ (between the mid-1980s and 2016) in terms of the degree of their leaders' autonomy in candidate selection and control over party organization, two aspects that we consider related to 'decentralizing' v. 'centralizing' personalization.

First, overall, populist parties in general were roughly as personalized (in terms of either control of candidate selection or party organization) between 1985 and 2008 as they were between 2009 and $2016 .{ }^{15}$ Second, the two new populist parties we examine here seem as personalized as more traditional populist parties. But populist parties, including Podemos and the M5S, are generally more centralized overall than other mainstream European parties (see Table A and Figure B in the Online Appendix) on all three dimensions.

Additionally (again see Figure 1), some interesting differences between Podemos and the M5S emerge, especially concerning the concentration of power around the leader. According to the expert survey, in Podemos, the leader has a great deal of power over both the selection of candidates (mean value 7.1) and the organization (7.9). Conversely, the leader of the M5S has more organizational control (9.4) but lower autonomy in candidate selection (6.43; see Table A in the Online Appendix) than Podemos. Podemos is overall more in line with its Western European populist counterparts, whereas the leader of the M5S has greater control over the party.

Finally, in looking at broader aspects of the personalization of politics, two notable trends emerge (see Table A in the Online Appendix): First, the level of personalization in all political parties in Spain increased after Podemos emerged (7.86 in 2015 and 7.43 in 2016 compared with the previous 30 years of general elections); the same is not true for Italy since the entrance of the M5S. This observation does not imply causality, as it may be the consequence of other forces, such as polarization or mimetic effects. Second, both the M5S and Podemos are more personalized in terms of policymaking agenda-setting (i.e. the leader has more power) 


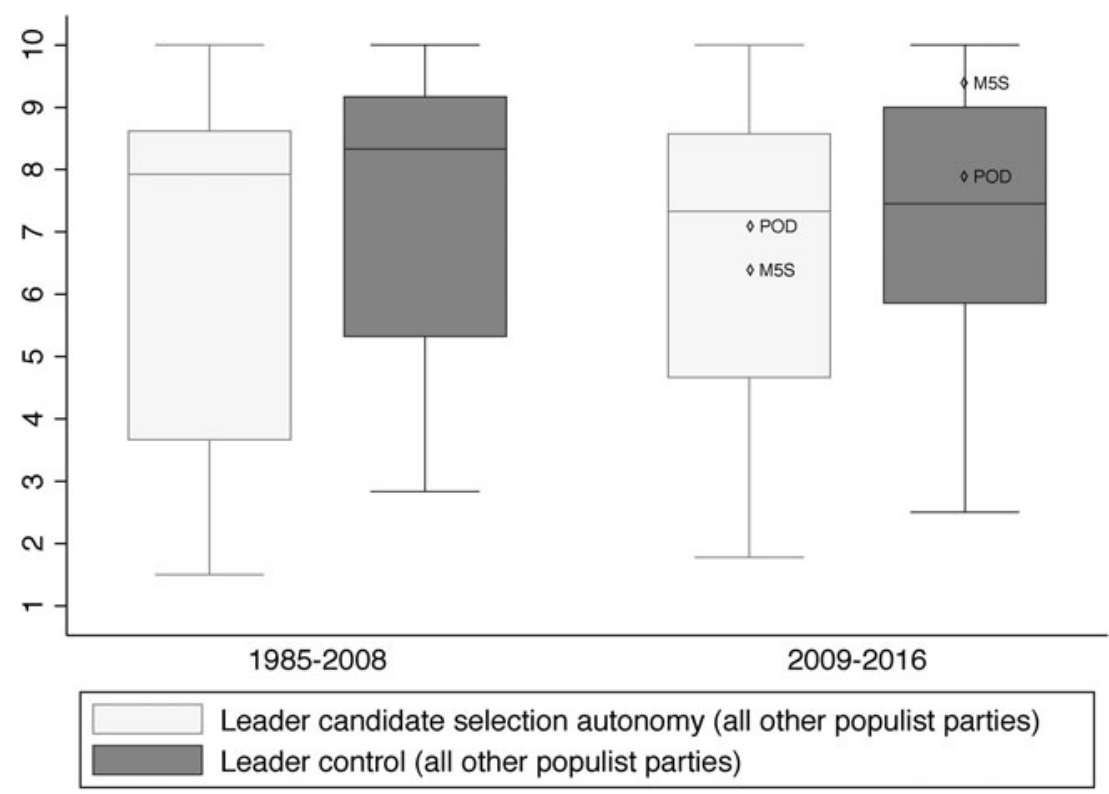

Figure 1. Leader Selection Autonomy and Control over the Party, in Podemos and the M5S v. All Other Populist Parties in Western Europe (1985-2016)

Source: PoPES data set 2020.

Note: The two variables have been coded using a scale from 1 (low autonomy) to 10 (high); for details about the survey questions, see the related footnotes. The symbol ' $\checkmark$ ' indicates the mean values of the M5S and Podemos. Each box includes values from the first to the third quartile, the horizontal line inside each box represents the median. The vertical lines outside the box represent the range of data included within 1.5 inter-quartile ranges below the first quartile or above the third quartile.

than the other mainstream/traditional political parties in their respective countries. In Table 1, we qualitatively summarize the overall picture of personalization in Podemos and the M5S measured according to these variables. ${ }^{16}$

In sum, our analysis shows that Podemos is a typical case of the personalization of politics within populist parties, whereas the M5S is something of a deviant case (see also Figure $\mathrm{C}$ in the Online Appendix). Podemos demonstrates a centralized personalization of politics, with strong leader autonomy in the selection of the party elites and control over the organization (more or less in line with other Western European populist parties). In the M5S, a more erratic picture emerges, one with two contrasting impulses: one towards a centralized personalization (in terms of the leader's control over the party's policymaking) and the other towards a decentralized personalization (Balmas et al. 2014), given the leader's relatively low autonomy regarding candidate selection. These countervailing forces allude to a peculiar configuration of power or logic of centralization.

Is there something structurally different between Podemos and the M5S concerning the intra-party personalization of politics? How does candidate selection actually work in these two parties? Do their differences and similarities influence the outcomes of their selection processes? The following sections will address these topics. 
Table 1. Centralization of Power and Personalization in Podemos and the M5S (national elections 19852016) (mean values)

\begin{tabular}{|c|c|c|}
\hline Personalization of politics & $\begin{array}{l}\text { Podemos } \\
\text { (Spain) }\end{array}$ & $\begin{array}{l}\text { M5S } \\
\text { (Italy) }\end{array}$ \\
\hline $\begin{array}{l}\text { General impact of personalization in electoral competitions } \\
\text { (since new populists in elections) }\end{array}$ & + & - \\
\hline Leader influence on party agenda and policymaking & + & + \\
\hline Leader autonomy in candidate selection & $\stackrel{+}{(7.1)}$ & $(6.4)$ \\
\hline Leader control over the party & $\stackrel{+}{(7.9)}$ & $\stackrel{+}{(9.4)}$ \\
\hline
\end{tabular}

Source: Authors' elaboration from the PoPES data set 2020.

Notes: + = high (on the 1-10 scale); - = low or moderate (on the 1-10 scale). * but not lower than the mean values of the Italian party system. The bold columns indicate the dimensions considered in this article.

By better understanding these differences, we hope to identify specific paths of personalization in populism, allowing us to identify subtypes of the same outcome.

\section{Candidate selection, party organization and personalization in Podemos Leader/organization}

\section{Party statutes and power distribution}

Despite its early origin in the Indignados movement (Díez García 2015), Podemos was conceived by a few intellectuals in 2014 as a 'maquina de guerra electoral'. Its vote-seeking strategy dictated its organizational structure. ${ }^{17}$ As one inner member stressed, 'in spite of an excess of centralism, it was necessary to build a vertical structure for both electoral and organizational purposes' (ID 4). ${ }^{18}$

An analysis of the party statutes (Podemos 2014, 2017a, 2017b) shows a hierarchical distribution of power at all levels (from national to local), centred on the leader(s). Although the internal organs of the party are elected through an online voting process involving all members (and membership is free of charge), the general secretary retains many crucial powers: the 'political and institutional representation' of the party (Statute 2014: Art. 24); the power to appoint members of the 'Coordinating Committee', a sort of secretary's cabinet (Art. 27); and, finally, to participate in the 'Citizens' Congress' (one of the most important committees of the party, which has 'political direction' and 'executive functions') (Art. 16).

This structure ensures that the secretary general, currently Iglesias, has nearly full control of the party. Party militants and local representatives underline the crucial role of the electoral system 'listas planchas' (ID 3, 4, 5, 8) used to elect both candidates for elections (at national and local levels) and other party officials (see below). Interviewees emphasized that 'Podemos never presented itself as a vehicle to challenge representative democracy' or as a 'leaderless party' (ID 5), but that it was always 'deeply centred around its founder and leader' (ID 3, 4, 6, 8).

\section{Party and civil society}

Some statute provisions seem to allow for citizens' participation in party direction. For example, members can submit proposals for the electoral manifesto and 
parliamentary debates (Statute 2014: Art. 12.3.d) ${ }^{19}$ and online referenda can remove internal officials, even the general secretary, and be used to vote on major strategic issues of the party agenda (Gerbaudo 2018). However, these mechanisms are difficult to use and the high thresholds for referenda (e.g. $10 \%$ of the members or $20 \%$ of the local sections, Statute 2014: Art. 14) mean that they are uncommon. As our interviewees explained, 'these provisions often served more the purpose to consolidate a certain democratic and bottom-up image of the party vis-à-vis the traditional Spanish ones than to concretely allow for participation' (ID 7, 11). These mechanisms became methods for the ratification of proposals from above, where 'the control of the issues under discussion by the party's leaders often lead to pre-determined results' (ID 11), or to plebiscitarian effects (Deseriis and Vittori 2019).

Furthermore, many of Podemos's middle-level cadres lamented the lack of internal democracy and the verticalization of the party (e.g. ID 1, 2, 4, 9, 23, 24, 25). At the same time, however, they also tended to justify the party's hierarchies (for example by emphasizing the limits of online activism v. offline militancy, e.g. ID 7,11$){ }^{20}$

In summary, our qualitative analysis confirms our quantitative observations, namely that the Spanish case shows a significant degree of centralization of power around the leader. This was not a later-stage development; rather, it has been the party's basic strategy since its inception (Izquierda Anticapitalista 2013).

\section{Leader/elections}

Selection of candidates for elections and internal roles

In the listas planchas system (used until mid-2016), voters elected their preferred candidates by picking individuals from different slates or by selecting all the candidates from a single slate. This procedure clearly favoured the list headed by Pablo Iglesias, who could use his resources and popularity to get his preferred candidates elected (Pérez-Nievas et al. 2018: 138). Our interviewees clarified that this meant that the endorsement of specific slates by the party's leaders in Madrid was crucial to the selection of candidates at the local level ('almost everywhere there was a slate that was clearly perceived as pablista and endorsed by the party in the capital', ID 6). The leaders 'dominated the entire selection process, placing loyal local leaders in key organs at the subnational level' (e.g. ID 4, 8, 9).

Through this system, Podemos's leadership consolidated its power and limited 'the emergence of autonomous political figures from the periphery' (ID 4). Only especially visible local candidates were able to induce a more decentralized selection process (ID 10, 11). In the 2015 Spanish national elections, party elites blocked non-aligned candidates using the listas planchas procedure and allowing a single national district to choose the candidates (ID 3,4). Iglesias had (and still retains) the right to modify the composition of the lists (as happened in the regions of Galicia and Valencia) (Podemos 2015: Art. 7.2).

\section{Symbolic tools and party culture}

Despite the centrally controlled selection of candidates, many of our interviewees maintained that 'the formation of spontaneous leaders was prevented, but this was necessary at that time' (e.g. ID 3). In fact, the party forcefully defends its 
vertical organization in public discourse, while respecting the Indignados tenets, giving the organization a 'vestige of internal democracy' (ID 7, 11). It often stresses the 'goal of citizens' political participation', the 'need to avoid a separation between online and offline party activism' (Podemos 2014: Art. 7.2 and 52.1) and Podemos's 'distance from the old traditional left characterized by sectarianism and inaccessible language' (Iglesias 2015: 15, 25). ${ }^{21}$ Nevertheless, these principles are then subsumed under the master frame of 'the need to build a party coherent and efficient enough to win elections' (ID 6, 8). Our interviewees justified the 'limitations of power [of] local sections with the higher importance the party offline militants and rank-and-files should have' (ID 5, 11).

The party often stresses its 'democratic culture' and operations in its statutes (e.g. Statute 2014: Annex 1). But while its official documents emphasize provisions for democratic participation, 'the contradiction between the formal and informal mechanisms of Podemos's internal organization and policymaking was [increasing] under the eyes of everybody' (ID 6), creating fertile ground for potential (mainly centre/periphery) cleavages within the party. As one local representative explained, 'the transmission belt between Madrid and us was the CEPS, a political think-tank with which many Podemos leaders worked' (ID 6). ${ }^{22}$ Despite the appearance of a cohesive elite, a minority faction (the 'Anticapitalist Left') has been increasingly vocal about Podemos's undemocratic internal organization (ID 1, 4). Overall, however, Podemos's candidate selection process remains extremely centralized.

\section{The consequences}

Unfortunately, this vertical architecture produced several unintended outcomes which undermined members' perceptions of the party's 'democratic image' (ID 25). Consequently, power centralization increased (see Podemos 2017a, 2017b), complaints from below emerged and factionalism festered, culminating in a schism. These steps followed a chronological path.

From the outset, rank-and-file members criticized the process for selecting internal party leadership (e.g. ID 1, 2, 4). As a founder of the party admitted, 'the problems [such as internal fights and desertions] erupted when we did not know anybody at the local levels, and the choices of trustworthy cadres to be endorsed were made in an extremely weak way ... just asking people during party rallies to join [the] Iglesias slate' (ID 3). As the party consolidated and membership increased, the centralized organizational structure became more difficult to manage. ${ }^{23}$ Tensions between the centre and the peripheries arose, stemming from the questions of candidate selection and setting the party's agenda. This disagreement 'caused the exit from the organization by prominent leaders at the local level' (ID 11, 24, 25). Conflicts regarding candidate selection sometimes motivated intervention from the centre and the removal of previously 'loyalist' local elites (ID 11). These divisions 'undermined the image of party cohesion and its strength ... despite the real numbers of the organization which were still relevant' (ID 25).

Strategic party alliances for the elections further exacerbated internal tensions (not only with the small Anticapitalist splinter, but also within the 'old guard' itself), and two factions emerged: one more open to flexible collaborations ('for immediate policy gains' ID 1), and one more reluctant (and keen to return to 'street 
and movement politics', ID 2,6,7). As a result, many members thought that the 2016 national elections and controversial alliance with the United Left party was 'a dismissal of some of the central principles of Podemos' (ID 4, 23).

At the 2017 party congress, two factions openly competed for control of the organization's central organs. Iglesias triumphed over Errejón's faction (Podemos 2017b: 11), and the challengers split from the party (ID 1,2). By using this method of resolution - solving factions' disagreements through open clashes - Podemos resembles a traditional mass party more than the M5S, where 'unanimity' is valued and factionalism is highly condemned. Later, during the primaries for the 2019 Spanish national elections, Iglesias's slate occupied the first 105 positions out of 350 , and several figures close to Errejón abandoned the party. ${ }^{24}$ The splinter group independently ran for the presidency of the Madrid region, against Podemos.

Podemos's highly vertical structure unintentionally turned the party's participatory features into formal arrangements that led to strong plebiscitarian effects. Minority factions opted to voice their displeasure (the Anticapitalist Left), or exit from the party (the errejonistas). Because Iglesias supporters dominate the party's central office, Podemos possesses high levels of party discipline at the top (Nez 2017); however, maintaining cohesive leadership has come at the cost of provoking internal schisms. Internal dissent has not been silenced, but overthrowing Iglesias's leadership is practically impossible. Figure D in the Online Appendix illustrates Podemos's logic of centralization.

\section{Candidate selection, party organization and personalization in the M5S Leader/organization}

Party statutes and power distribution

Since its foundation in 2009, the M5S has defined itself as a post-ideological movement, aiming to promote participatory, direct, web-based democracy (Musso and Maccaferri 2018). In addition to anti-establishment ideas, Grillo, its leader, emphasized making the party 'truly accountable' to the voters: public representatives are 'mere speakers' for citizens and 'executors of the party manifestos' (as our interviewees emphasized, ID 19, 20,26) - which, in line with party principles, 'are elaborated and voted by the members' (ID 12,15). This participatory rhetoric informed the M5S's internal organization and operations.

The party's first 'Non-Statute' (M5S 2009), drafted by Grillo and Casaleggio (see also Ceri and Veltri 2017), included many personalist features: no mediation between the leader, the voters and the members; an extremely weak organizational party structure, which was to revolve around online arenas and informal arrangements of decision-making; and the absence of intermediary organs. Although Grillo has full ownership of the party name and logo (M5S 2009: Art. 3), the M5S is defined as 'a platform of discussion and consultation which originates ... from the blog www.beppegrillo.it' (Art. 1), with 'neither formalized membership nor formal organizational structure' (M5S 2009: Art. 4, 5). However, the party leadership (Grillo and formerly Casaleggio, until his death in April 2016) has the responsibility of determining rules for party membership and candidacy (see below).

The next party statute (M5S 2017a) reproduced similar centralizing and personalizing tendencies, but it also formalized some new party offices: internal organs 
controlling 'disciplinary measures' (e.g. against candidates and representatives accused of 'promotion, organization and participation in "restricted groups"' (M5S 2017a: Art. 9.b.3) or the 'lack of cooperation and coordination with other members, also within parliamentary groups' (Art. 9.c.3)), the 'guarantor' of the party (an ad vitam role occupied by Grillo) with the power to 'defend the M5S's core values' (Art. 8), and the 'political chief' (with the power to initiate 'online referenda; [maintain] the political unity of the M5S; [and coordinate] the party representatives, parliamentary whips, and members of the government' (Art. 7)). Grillo held a prominent role within the organization, proclaiming himself its 'political chief until October 2017. No other intermediary roles or bodies were created until 2019. In sum, fully centralized, personalist leadership governs the M5S.

\section{Party and civil society}

The M5S also possesses several organizational features intended to guarantee citizens' participation in the party. The most important mechanism is the party's online platform, Rousseau (created in 2015 as an innovative tool, Deseriis 2017), ${ }^{25}$ through which M5S members can: (1) advance (Lex Iscritti) or suggest amendments or bills at any territorial level (Lex Regioni, Lex Parlamento and Lex Europa); (2) draft and vote on the party's electoral manifestos; and (3) select candidates for elections and, more recently, internal leadership positions.

This platform was intended to be an arena for collective decision-making on key issues, the organization of party rallies, events and campaigns, and (especially since 2017) the election of the party's few official roles. In practice, it is 'little more than a mere declaration of principle' (ID 22, 27, 28) and most important decisions are generally made by the party elites (Gerbaudo 2018). Our interviewees explained that the so-called collective drafting of party manifestos was actually the 'simple ratification' of priorities dictated by party elites (ID 15, see also Ceri and Veltri 2017); similarly, leaders - not the popular forum - decided on the party's strategic alliance and drafted the statutes (Deseriis and Vittori 2019). Likewise, bill amendments and proposals posted in Rousseau were few and extremely vague, and they had very little influence on parliamentary proceedings (ID 16, 28; see also Deseriis and Vittori 2019; Tronconi 2015). The M5S 'has in practice developed an internal organization that ensures the founders with strong and unchallengeable control over the party' (ID 13, 22).

These ineffective online tools garner low levels of participation. For instance, between 2016 and 2019, various calls for advancing bill proposals received (on average) no more than 14,000 voters, out of more than 100,000 party members. Likewise, online voting sessions for the party manifestos saw only 17,000 voters on average (Vittori 2020).

In summary, the qualitative analysis mirrors the quantitative observations. The organization is strongly centralized and personalized. Furthermore, tension between party philosophy and praxis also affects the selection of the M5S's candidates.

\section{Leader/elections}

Selection of candidates for elections and internal roles

Just like the M5S's decision-making procedures, many activists perceived elections for the party's internal positions as plebiscites on candidates appointed by Grillo 
and Casaleggio. ${ }^{26}$ In the early phase of the party, local activists enjoyed a large degree of autonomy in their internal organization, agenda-setting and, most importantly, candidate selection for municipal elections (e.g. ID 12, 14, 16, 18, 20). In 2007, 'in order to prevent some groups from independently pursuing electoral goals' (ID 13), party leaders invited local groups of activists (using the software MeetUp) to discuss and organize 'social campaigns' on issues of interest and to select candidates for local elections (Grillo 2007). ${ }^{27}$ These meetings led to the creation of a sort of franchise network of autonomous electoral lists (Liste Civiche Certificate), which had to gain permission to use the party logo (Ceri and Veltri 2017), but they were 'really autonomous both in terms of their programmatic manifestoes and the selection of the candidates' (ID 15, see also ID 20). Restrictions on candidacy only included terms of previous public office roles and the existence of legal charges (Ceri and Veltri 2017).

Between 2009 and 2013, the selection of candidates for local elections followed a variety of procedures (Lanzone 2012): some were online through the MeetUp galaxy (hosted on Grillo's blog); others used different, independent online platforms (ID 20,30); local sections of the party also (more rarely) organized offline assemblies (ID 12, such as in 2012 in Sicily).

In the primaries for the national elections in 2013, the M5S imposed stricter limits on candidacy and the selectorate than even those of Podemos: only candidates belonging to a Lista Civica Certificata could be chosen (to avoid infiltration). ${ }^{28}$ Although these limitations ordinarily characterize a 'closed' candidate selection process (e.g. Lanzone and Rombi 2014; Mikola 2017), Grillo and Casaleggio did not endorse any candidates, and en bloc voting was not allowed. The results were quite unpredictable, as many interviewees noted, and they brought relatively unknown people to parliament ('I was living in my farm, not even following Grillo's blog regularly; I decided to run, and I was elected. Of course, some candidates had better networks than others, as those introduced by Casaleggio, but this was the exception. I could enter the parliament and I was an unknown citizen!' ID 21, see also ID 16).

At the same time, however, Grillo was tightening his control over the party's organization (especially from 2012) through infamous 'expulsions'. Several activists were expelled from the party for 'criticizing the centralization of the organization and trying to develop autonomous MeetUps at the local level' (ID 13) or because they disobeyed the ban on TV appearances (Corbetta and Gualmini 2013). Local representatives were prevented from increasing their visibility as 'local stars' (ID 13), and party leadership blocked potential avenues of decentralization. While the process of candidates' selection later became (i.e. national elections 2018) even more centralized (see the following section), in an earlier phase it was possible to keep it ostensibly open, precisely because the leaders were able, in fact, to strictly control the party organization with various organizational (and ideological) arrangements.

\section{Symbolic tools and party culture}

M5S MPs are, in fact, under the full control of the party leadership. Party representatives eventually became the only ones legitimately allowed to 'speak on behalf of the M5S' because they 'received the popular legitimation to implement the 
manifesto' (ID 19). Paradoxically, Rousseau widened the chasm between the leadership and the rank and file by granting online members only a formal role in the party. The real and perceived importance of the offline activists (i.e. participants of MeetUps), who lack formal power within the organization and assume a role only during local electoral campaigns, declined, and those members have little bearing on the party's agenda-setting and strategy (ID 27).

Additionally, soon after the M5S gained seats in parliament, its leadership developed tools to retain control over the party in public office: communication groups and committees. Communication groups (consultants from Casaleggio's web-based marketing firm) are supposed to support the parliamentary groups at the national and EU levels. Although legislative activity is ostensibly independent of the communication groups (e.g. ID 14,15,16,17, 'but only when a topic is not relevant', ID 21), the groups decisively influence the party's agenda ('suggesting - as a representative of the party stresses - which issues have to be discussed when parliamentary sessions are broadcast on public television', ID 16) and electoral manifestos (ID 15). Another central task of communication groups is 'to collect information about the MPs and identify the loyal and the disloyal ones' (ID 13). The party leadership justifies these activities as the need to '[select] those MPs with higher communicative abilities' (ID 16).

The party leaders install prominent, loyal members on committees with vague 'communication and coordination functions' (such as the 'directorate', nominated by Grillo in 2014 (La Repubblica 2014), or the Rousseau Association, created in 2016, ID 17). According to many interviewees, the absence of a formal party structure allows leaders to retain and increasingly exert substantial control over the party.

\section{The consequences}

The M5S's vertical party architecture and its internal operations (including the candidate selection process) have produced several effects, which, as in Podemos, undermine its democratic credentials. These include: (1) further power centralization by the leadership (as in Podemos); (2) decreased (offline) membership (as in Podemos) and decreased power of the party on the ground vis-à-vis both the leadership and the party in public office (as in Podemos; although in the M5S the party in public office is more central and de facto overlaps with party cadres); and (3) a high degree of cohesiveness among remaining party membership coexisting with the departure of several prominent figures (as opposed to internal factionalism and schism of Podemos).

As of 2018, the M5S's political chief has the right to choose candidates for the uninominal districts in general elections (M5S 2018: part 2, Art. 1), while plurinominal primaries were theoretically open to all members. However, candidacy is still controlled by the guarantor and the political chief (so only those 'compatible with values and policies of the M5S' can run, M5S 2018: Art. 7). This framework prevents the creation of overt factions within the party, since loyalty is the most effective strategy for acceding to primaries and then for increasing chances of winning them. Despite the potential ideological heterogeneity among representatives directly appointed by the political chief (i.e. external, well-known candidates who may be less committed to the party's principles are often chosen to increase the 
party's electoral appeal), the new rules for candidate selection tightened the leadership's control over the party in public office - which is key to understanding the beginning of the M5S's experience in government. Overall, we conclude that the candidate selection process was much more unpredictable (and less determined by leaders' preferences) in 2013 than in 2018, when the M5S clearly aimed to govern the country.

This mix of formal rules, informal arrangements and political culture effectively discouraged the organized expression of dissent within the party (i.e. factionalism, splintering) but nurtured individual departures. Of the M5S's MPs, $24 \%$ abandoned (or were forced to leave) the parliamentary group between 2013 and 2018, and after less than two years, 31 out of 338 MPs had quit (or been ousted by) the M5S's parliamentary groups (Cottone 2020; OpenPolis 2018). ${ }^{29}$ In the words of one interviewee, 'according to the political culture of the M5S, factionalism is strongly condemned, as it is seen as a typical feature of the old mainstream Italian parties and a betrayal of the popular mandate' (ID 19).

Recently, the influence of the party on the ground has further declined, as evidenced by the selection of candidates (in the 2018 elections, former MPs led 63 out of 95 lists at the district level, and bottom-up candidates won in 14 districts). As a M5S activist explained, there is 'an increasing divide between our representatives and the MeetUps, which often experience internal divisions following personalist linkages with our representatives' (ID 27). We hypothesize that this division is the cause of the current stagnation of M5S membership and the party's failure in the 2019 municipal elections, when offline activists were so low in number that some were unable to form electoral slates. ${ }^{30}$

One could ask whether the changes in the M5S's candidate selection process (2018 v. 2013) are the outcome of or path to a certain party model. Our analysis suggests that the tightening of control over this process was mostly connected to two interrelated party goals: to increase its electoral appeal and its control on the parliamentary groups in order to guarantee more discipline in times of governmental access. In sum, the original unpredictability of the M5S's candidate selection process at the end clashed with the strategic reasoning of the party.

Table 2 synthetizes similarities and differences between Podemos and the M5S on the aspects examined so far, highlighting two different logics of centralization of power and their consequences (see also Figure D in the Online Appendix).

\section{Conclusion}

In this article, we focused on the candidate selection processes of Podemos and the M5S - a representation of IPD in these new left-wing or hybrid parties of Southern Europe. With a mixed-methods approach and a comparative perspective, we explored candidate selection longitudinally, locating it against the background of broader party structures and functions.

From an empirical viewpoint, we have shown that, in line with other studies (Lanzone and Rombi 2018; Pérez-Nievas et al. 2018), these parties' participatory and radically democratic rhetoric does not match the rules and practices of candidate selection. The idea that power in new populist parties of Southern Europe is concentrated in their leadership is not new (Cordero et al. 2018; Deseriis and 
Table 2. Two Different Logics of Centralization and Top-Down Relations, in Podemos and the M5S

\begin{tabular}{|c|c|c|}
\hline & Policy & Outcome \\
\hline \multicolumn{3}{|c|}{$\begin{array}{l}\text { Leader/organization } \\
\text { Origin }\end{array}$} \\
\hline Podemos & $\begin{array}{l}\text { Participation: Party created from above and } \\
\text { fuelled by below }\end{array}$ & \multirow[t]{2}{*}{ Centralization prevails } \\
\hline & $\begin{array}{l}\text { Elitism: Small group of intellectuals }+ \text { high } \\
\text { personalization }\end{array}$ & \\
\hline M5S & $\begin{array}{l}\text { Participation: Franchise party with } \\
\text { autonomous local units controlled by } \\
\text { the leadership }\end{array}$ & \multirow[t]{2}{*}{ Centralization prevails } \\
\hline & $\begin{array}{c}\text { Elitism: Extreme personalization until 2013- } \\
14+\text { power delegation to loyal figures }\end{array}$ & \\
\hline \multicolumn{3}{|c|}{$\begin{array}{l}\text { Leader/organization } \\
\text { Party statute }\end{array}$} \\
\hline \multirow[t]{2}{*}{ Podemos } & $\begin{array}{l}\text { Participation: Statute 2014: candidate } \\
\text { selection and elections for internal } \\
\text { organs through open internal voting; } \\
\text { Provisions for internal referenda }\end{array}$ & \multirow[t]{2}{*}{ Strong centralization } \\
\hline & $\begin{array}{l}\text { Elitism: Elections of internal organs and } \\
\quad \text { candidate selection (until 2016), through } \\
\quad \text { listas planchas; } \\
\text { Very high thresholds; } \\
\text { Hierarchical organization dominated }\end{array}$ & \\
\hline M5S & $\begin{array}{l}\text { Participation: 'Non-Statute' 2009: open } \\
\text { membership with no fees; } \\
\text { Provisions for internal referenda for } \\
\text { sensitive issues and to elect the political } \\
\text { chief }\end{array}$ & \multirow[t]{2}{*}{$\begin{array}{l}\text { Nearly unchallengeable } \\
\text { centralization }\end{array}$} \\
\hline & $\begin{array}{l}\text { Elitism: 'Non-Statute 2009: party's logo as } \\
\text { property of the party founder; } \\
\text { Internal referenda convoked by the } \\
\text { 'political chief' (Statute 2017); } \\
\text { Grillo and Casaleggio hold the right to } \\
\text { intervene on party agenda (Statute } \\
\text { 2017); } \\
\text { (Since 2019) creation of formal party } \\
\text { structure for coordinating purposes }\end{array}$ & \\
\hline \multicolumn{3}{|c|}{$\begin{array}{l}\text { Leader/organization } \\
\quad \text { Relationship with civil society }\end{array}$} \\
\hline Podemos & $\begin{array}{l}\text { Participation: Online referenda and } \\
\text { signatures }\end{array}$ & \multirow{2}{*}{$\begin{array}{l}\text { Centralized (this aspect not so } \\
\text { central for the party identity, } \\
\text { see below) }\end{array}$} \\
\hline & Elitism: BUT limits imposed by thresholds & \\
\hline M5S & $\begin{array}{l}\text { Participation: Online amending and } \\
\text { proposing bills and manifestos }\end{array}$ & \multirow{2}{*}{$\begin{array}{l}\text { Centralized (although this } \\
\text { aspect rhetorically central for } \\
\text { the party identity, see below) }\end{array}$} \\
\hline & $\begin{array}{l}\text { Elitism: Participation of few people } \\
\text { participate mere ratification of } \\
\text { manifestos from above }\end{array}$ & \\
\hline
\end{tabular}


Table 2. (Continued.)

\begin{tabular}{|c|c|c|}
\hline & Policy & Outcome \\
\hline \multicolumn{3}{|c|}{$\begin{array}{l}\text { Leader/elections } \\
\text { Candidates' selection (rules and procedures) }\end{array}$} \\
\hline Podemos & $\begin{array}{l}\text { Participation: Elections of every party organ } \\
\text { and of candidates }\end{array}$ & \multirow[t]{2}{*}{$\begin{array}{l}\text { De facto centralized candidate } \\
\text { selection }\end{array}$} \\
\hline & $\begin{array}{l}\text { Elitism: BUT internal elections organized } \\
\text { through formal and informal } \\
\text { endorsements from the top; } \\
\text { Primaries for the legislative elections; } \\
\text { Leader's right to modify the lists' } \\
\text { composition }\end{array}$ & \\
\hline \multirow[t]{2}{*}{ M5S } & $\begin{array}{l}\text { Participation: 'Non-Statute' } 2009 \text { + Statute } \\
\text { 2017: candidate selection from below for } \\
\text { elections; } \\
\text { No endorsements of candidates }\end{array}$ & \multirow[t]{2}{*}{$\begin{array}{l}\text { Decentralized candidate } \\
\text { selection but strong control } \\
\text { over parliamentary group }\end{array}$} \\
\hline & $\begin{array}{l}\text { Elitism: BUT parliamentary groups } \\
\text { controlled; } \\
\text { Internal inner circle; } \\
\text { Control on the candidacy for internal } \\
\text { primaries; } \\
\text { Political chief has the right to appoint the } \\
\text { candidates for uninominal districts in } \\
\text { legislative elections }\end{array}$ & \\
\hline \multicolumn{3}{|c|}{$\begin{array}{l}\text { Leader/elections } \\
\text { Party ideology/'culture' }\end{array}$} \\
\hline Podemos & $\begin{array}{l}\text { Participation: Adoption of Indignados } \\
\text { rhetoric + democratic methods (e.g. } \\
\text { internal voting) }\end{array}$ & \multirow[t]{2}{*}{ Centralized } \\
\hline & $\begin{array}{l}\text { Elitism: BUT building of a leader-centred } \\
\text { organization and rhetoric; } \\
\text { Empowerment of online membership }\end{array}$ & \\
\hline M5S & $\begin{array}{l}\text { Participation: Leaderless and direct } \\
\text { democracy rhetoric }\end{array}$ & \multirow[t]{2}{*}{ De facto extremely centralized } \\
\hline & $\begin{array}{l}\text { Elitism: Extremely tight party discipline; } \\
\text { Explicit condemnation of factionalism; } \\
\text { Few instruments to express dissent }\end{array}$ & \\
\hline \multicolumn{3}{|c|}{ Consequences/effects } \\
\hline Podemos & $\begin{array}{l}\text { Further power centralization; } \\
\text { Internal complaints for lack of } \\
\quad \text { participation; } \\
\text { Digital plebiscitarianism: } \\
\text { Factionalism and schisms }\end{array}$ & \\
\hline M5S & $\begin{array}{l}\text { Further power centralization; } \\
\text { Loss of relevance of offline membership } \\
\quad \text { with negative effects on elections at the } \\
\quad \text { local level; } \\
\text { Exit of dissidents; } \\
\text { Expulsions; } \\
\text { Creation of 'personalist factions' }\end{array}$ & \\
\hline
\end{tabular}


Vittori 2019; Gerbaudo 2018), but by disentangling personalization and centralization, we can better understand the mechanisms of power consolidation.

Despite their commonalities, the two parties' candidate selection processes and logics of centralization are distinct. As expert survey data show, the leader of Podemos appears equally strong in both arenas (i.e. candidate selection and organizational control) and in general Podemos resembles a typical personalized party (or 'centralized personalization' (Balmas et al. 2014)). In the M5S, the loci of power go in two apparently opposite directions: the leader has control over party organization, but emerges weaker in candidate selection, presenting a sort of deviant case.

From a theoretical viewpoint, our results contribute to the literature on IPD and personalization of politics, critically addressing the complex relationship between 'personal parties', populism and scant organizational resources. We offer a limited empirical contribution that problematizes these three aspects. The formal rules and procedures for candidate selection may appear to be open (i.e. democratic, bottom-up), suggesting a sort of 'decentralized personalization' (Balmas et al. 2014), while the leadership maintains strong, top-down control through the rigid centralization of other aspects (i.e. control of party representatives through the appointment of loyal actors, party discipline and the plebiscitary effects of online consultation). In both populist parties, the organization of the party and its rhetoric emerged as crucial in justifying the centralization of power.

Although some authors (e.g. Albertini 2019; Lanzone and Rombi 2018; Mikola 2019) consider the M5S's candidate selection process closed, ${ }^{31}$ we argue that party leadership allowed instead an open process, coherent with its anti-caste identity (at least in 2013), because both formal and informal organizational arrangements circumscribe MPs' autonomy. Five years later, however, leadership made the candidate selection process much more predictable. On the other hand, Podemos is characterized by a relatively closed process of candidate selection, despite its high formal inclusiveness in terms of candidacy and selectorate. This leads to primaries' results that 'resembled ... a system of direct appointment by the party leader', or decision-making power restricted to a limited oligarchy (Pérez-Nievas et al. 2018: 141-142). Centralized personalization comes with its own challenges for party cohesion and stability, given 'more personally powerful leaders will be ... more susceptible to personal failure and defeat, as well as triumph' (Balmas et al. 2014: 47).

In general, we argue that accurately assessing the inclusiveness of a candidate selection process requires understanding the party's broader infrastructure and the relationship between the party in the central office, in public office and on the ground (Katz and Mair 1993; see also Vignati 2015a, 2015b). Only this kind of contextual understanding can account for why we might see unexpected outcomes from formally closed candidate selection processes (as in 2013 with the M5S) and the reverse (Podemos's formally open procedures producing centrally determined results). Different logics of centralization (or internal configurations of power) also have different consequences, both in terms of internal democracy (which is, in both cases, undermined) and of party organization (expulsions and departures in Italy and splintering and schisms in Spain).

In this sense, our study confirms and refines the hypothesis of those (Katz and Mair 1995; Musella 2018) who link an open selectorate to a closed process of candidate selection, or the decreasing of power of activists within a party. We 
emphasize the need to study candidate selection and party organization together. ${ }^{32}$ We do not find, as shown in the case of the M5S, that a more open candidate selection process favours decentralized personalization, nor do we confirm the assumed positive relationship between (high) IPD, (open) candidate selection and (open, horizontal) party organization. These findings significantly broaden and refine our understanding of candidate selection processes and different logics of decisionmaking in populist political parties.

Supplementary material. To view the supplementary material for this article, please go to: https:/doi. org/10.1017/gov.2021.9.

\section{Notes}

1 Inclusionary populists are differentiated from exclusionary ones for their 'inclusive' position on the material, symbolic and political dimensions of populism (e.g. welfare universal programmes including immigrants, direct political participation from below, etc.; see Mudde and Rovira Kaltwasser 2013). For inclusionary populists, the outsiders are the economic and political forces threatening people's unity (Mudde and Rovira Kaltwasser 2013); they are more frequently associated with the radical left. Both the M5S and Podemos are commonly classified as inclusionary (Font et al. 2021; Roodujin et al. 2019), although the use of the 'left-wing' populism category for the M5S is highly contested (Bordignon and Ceccarini 2015; Corbetta 2018; Mosca and Tronconi 2019; Pirro 2018).

2 Current studies on the topic mainly focus on party statutes and other internal party documents (for a few exceptions, see Albertini 2019; Mikola 2019; Vignati 2015a, 2015b).

3 We are grateful to the referees' comments for this point.

4 The Personalization of Politics' Expert Survey (PoPES) was conducted in 2017 by the Centre for the Study of Political Change (CIRCaP, University of Siena). We are grateful for permission to use the data (Marino et al. 2020).

5 To be included in the PoPES, parties needed to obtain $5 \%$ of the votes in at least one general election in the period under consideration (mid-1980s-2016), and to be included in a single election, they needed to secure at least $1 \%$ of the votes.

6 The original question was: 'How would you evaluate the autonomy of party leaders in selecting candidates for general elections? ... 1-10 scale, where 1 means "very low autonomy" and 10 means "very high autonomy".' 7 The original question was: "How would you rate the control that party leaders have on party organization? ... 1-10 scale, where 1 means "very low control" and 10 means "very high control".'

8 The original question was: 'How would you evaluate the overall impact of the personalization of politics in each of the following general elections? ... 1-10 scale, where 1 means "very low impact" and 10 means "very high impact".

9 The original question was: 'How would you evaluate the autonomy of party leaders in defining the policymaking agenda of the party? ... 1-10 scale, where 1 means "very low autonomy" and 10 means "very high autonomy".'

10 For example, Southern European countries such as Greece, Italy, Portugal and Spain show particularly high values of party leader autonomy in candidate selection (whereas Finland, Germany, Iceland and Switzerland show particularly low values on this dimension); a more heterogeneous cluster (including Belgium, Iceland, Greece, Ireland, Italy, Portugal, Spain and the UK) is characterized by high scores on leaders' control of the party; in the same group of countries (except for Italy and Greece), leaders have a high degree of autonomy in influencing the party's policymaking agenda.

11 Each interview lasted for between one and three hours and was conducted in the participant's native language. The interviewees were selected according to a reputational method, and we tried to obtain a sample that reflected a range of genders, geographies national- and local-level representatives, militants and activists.

12 That is, who can select the candidates for the general election? Who can be a candidate? What is the voting method? Is the selection made at the central or at the local level?

13 We are very grateful to one of the anonymous referees for stressing this aspect.

14 The analysis includes both left- and right-wing populist parties: the BZO, the FPO, and Team Stronach in Austria; the Flemish Bloc in Belgium; the Danish People's Party in Denmark; True Finns/Finns Party in 
Finland; the Front National in France; the PDS/The Left in Germany; the Popular Orthodox Rally and Synaspismos/Syriza in Greece; Sinn Féin in Ireland; Forza Italia and the Northern League in Italy; the Party for Freedom in the Netherlands; the Swiss People's Party in Switzerland; and UKIP in the UK. We used the most widely accepted criteria to classify 'populist parties' (e.g. Roodujin et al. 2019; Zulianello 2020).

15 For example, the median, or the range of values included between the first and the third quartiles are similar in the two periods under investigation.

16 The quantitative disaggregated data are available upon request.

17 However, some movement-informed principles remained, such as the refusal to accept financial contributions from corporations and the commitment to member-elected internal party organs and candidates (Statute 2014: Art. 2.2.e).

18 'ID n' refers to quotes from our interviews. Please see List A in the Online Appendix for the list of interviewees.

19 Through the web platform Plaza Podemos, https://plaza.podemos.info/.

20 'These tools can be used to destroy politics instead of building it ... . Offline, committed activists should have more influence on the party' (ID 11).

21 See also the letter sent by Iglesias to the local sections of the party in 2014 (https://m.publico.es/columnas/110443866791/otra-vuelta-de-tuerka-circulos-podemos).

22 Other interviewees reported the creation of similar 'local inner circles' linked to the leaders from Madrid.

23 Membership increased from 205,000 in 2014 to 450,000 in 2017 to 520,000 in June 2019 (https://participa.podemos.info/es).

24 For the candidates, see https://primariascongresoysenado.podemos.info/resultados/el-congreso-de-losdiputados.

25 https://rousseau.movimento5stelle.it

26 Similarly, many rank-and-file members criticized the en bloc voting procedure for the election of the six 'organizational facilitators' (ID 20) and the creation of the informal 'directorate' in 2015 (ID 13, 20).

27 The MeetUps are the (informal) local sections of the M5S. Originally conceived as online forums created by Grillo followers, they later began to organize offline activities by themselves, such as meetings and participation in local elections (ID 20, 26, 31; Biorcio 2016).

28 www.beppegrillo.it/passaparola-comunicato-politico-numero-cinquantatre-beppe-grillo/.

29 However, some scholars now also identify factionalism within the M5S (Tronconi 2018: 172).

30 M5S membership reached roughly 150,000 members in 2017; it stood at 115,000 in September 2019. In the 2019 local elections, M5S lists were present in just 285 municipalities out of 3,793 (7.5\% compared with 2014's 14\%).

31 More precisely, it is said that the party's candidate selection process was exclusive in 2013 (because of strict candidacy requirements) and became more inclusive in 2018. This is exactly the opposite of what we argue in this study.

32 In principle, one could also find the opposite situation: a party with a very closed process of candidate selection coupled with a pluralistic and horizontal internal organization. This is for a debate about the definition of IPD.

\section{References}

Albert Z and La Raja RJ (2020) Who Should Decide the Party's Nominee? Understanding Public Attitudes Toward Primary Elections. Party Politics, published early online, March. https://doi.org/10.1177/ 1354068820913279.

Albertini A (2019) Populism and Democracy: Patterns of Intra-Party Participation in Comparative Perspective: The Case of Podemos and Five Star Movement. PhD dissertation, Scuola Superiore Sant'Anna.

Balmas M et al. (2014) Two Routes to Personalized Politics: Centralized and Decentralized Personalization. Party Politics 20(1), 37-51. https://doi.org/10.1177/1354068811436037.

von dem Berge B et al. (2013) Measuring Intra-Party Democracy. Heidelberg: Springer.

Biorcio R (ed.) (2016) Gli attivisti del Movimento 5 Stelle. Milan: FrancoAngeli.

Biorcio R and Natale P (2018) Il Movimento 5 Stelle: dalla protesta al governo. Milan: Mimesis. 
Blondel J and Thiébault JL (2010) Political Leadership, Parties and Citizens. Abingdon: Routledge.

Bordignon F and Ceccarini L (2015) The Five-Star Movement: A Hybrid Actor in the Net of State Institutions. Journal of Modern Italian Studies 20(4), 454-473. https://doi.org/10.1080/1354571X.2015. 1066112.

Ceri P and Veltri F (2017) Il Movimento nella rete. Storia e struttura del Movimento a 5 stelle. Turin: Rosenberg \& Sellier.

Chironi D and Fittipaldi R (2017) Social Movements and New Forms of Political Organization: Podemos as a Hybrid Party. Partecipazione e Conflitto 10(1), 275-305. https://doi.org/10.1285/i20356609v10ilp275.

Corbetta P (ed.) (2018) M5S: Come cambia il partito di Grillo. Bologna: Il Mulino.

Corbetta P and Gualmini E (2013) Il partito di Grillo. Bologna: Il Mulino.

Cordero G et al. (2018) The Effects of the Great Recession on Candidate Selection in America and Europe. In Coller X, Cordero G and Jaime-Castillo AM (eds), The Selection of Politicians in Times of Crisis. Abingdon: Routledge, pp. 262-277.

Correa P, Teruel JR and Barberà $\mathbf{O}$ (2018) Personalization of Politics and Leadership Stability in Western Europe. Paper presented at the 2018 ECPR Conference, University of Hamburg, 22-25 August.

Cottone N (2020) Cacciati o delusi: ecco i parlamentari che hanno lasciato il M5S. Il Sole 24 Ore, 24 January. www.ilsole24ore.com/art/cacciati-o-delusi-ecco-19-parlamentari-che-hanno-lasciato-m5s-ACAn3c9.

Cross WP (2008) Democratic Norms and Party Candidate Selection: Taking Contextual Factors into Account. Party Politics 14(5), 596-619. https://doi.org/10.1177/1354068808093392.

Cross WP and Katz RS (eds) (2013) The Challenges of Intra-Party Democracy. Oxford: Oxford University Press.

Díez García R (2015) Las bases sociales de la indignación: una perspectiva agregada sobre los factores asociados a la participación ciudadana en el movimiento 15M. Revista de Ciencias Sociales 238, 41-84.

Della Porta D et al. (2017) Movement Parties Against Austerity. Cambridge: Polity Press.

Deseriis M (2017) Direct Parliamentarianism: An Analysis of the Political Values Embedded in Rousseau, the 'Operating System' of the Five Star Movement. eJournal of eDemocracy and Government 9(2), 47-67. https://doi.org/10.29379/jedem.v9i2.471.

Deseriis M and Vittori D (2019) The Impact of Online Participation Platforms on the Internal Democracy of Two Southern European Parties: Podemos and the Five Star Movement. International Journal of Communication 13(2019), 5696-5714.

Font N, Graziano P and Tsakatika M (2021) Varieties of Inclusionary Populism? SYRIZA, Podemos and the Five Star Movement. Government and Opposition: An International Journal of Comparative Politics. 56(1), 163-183. https://doi.org/10.1017/gov.2019.17.

Freeman J (1986) The Political Culture of the Democratic and Republican Parties. Political Science Quarterly 101(3), 327-356. https://doi.org/10.2307/2151619.

Garzia D (2011) The Personalization of Politics in Western Democracies: Causes and Consequences on Leader-Follower Relationships. Leadership Quarterly 22(4), 697-709. https://doi.org/10.1016/j.leaqua. 2011.05.010.

Gerbaudo P (2018) The Digital Party: Political Organization and Online Democracy. London: Pluto Press.

Gerbaudo P (2019) Are Digital Parties More Democratic than Traditional Parties? Evaluating Podemos and Movimento 5 Stelle's Online Decision-Making Platforms. Party Politics, published early online, November. https://doi.org/10.1177/1354068819884878.

Grillo B (2007) Tutte le battaglie di Beppe Grillo. Milan: Casaleggio Associati.

Hazan RY and Rahat G (2010) Democracy Within Parties. Oxford: Oxford University Press.

Heinisch R and Mazzoleni $\mathbf{O}$ (eds) (2016) Understanding Populist Party Organization: The Radical Right in Western Europe. London: Palgrave.

Iglesias P (2015) Understanding Podemos. New Left Review 93(3), 1-22.

Ignazi P (2018) The Four Knights of Intra-Party Democracy: A Rescue for Party Delegitimation. Party Politics 26(1), 9-20. https://doi.org/10.1177/1354068818754599.

Ivaldi G, Lanzone ME and Woods D (2017) Varieties of Populism across a Left-Right Spectrum: The Case of the Front National, the Northern League, Podemos and Five Star Movement. Swiss Political Science Review 23(4), 354-376. https://doi.org/10.1111/spsr.12278.

Izquierda Anticapitalista (2013) Resolución de la Secretaría Confederal, Enlace N. 82. www.scribd.com/ document/201190008/Boletin-IA\#download\&from_embed. 
Karvonen L (2010) The Personalization of Politics. Colchester: ECPR Press.

Katz RS and Mair P (1993) The Evolution of Party Organizations in Europe: The Three Faces of Party Organization. American Review of Politics 14(4), 593-617. https:/doi.org/10.15763/issn.2374-7781. 1993.14.0.593-617.

Katz RS and Mair P (1995) Changing Models of Party Organization and Party Democracy: The Emergence of the Cartel Party. Party Politics 1(1), 5-28. https://doi.org/10.1177/1354068895001001001.

Kriesi H (2011) Personalization of National Election Campaigns. Party Politics 18(6), 825-844. https://doi. org/10.1177/1354068810389643.

Kriesi H (2014) The Populist Challenge. West European Politics 37(2), 361-378. https://doi.org/10.1080/ 01402382.2014.887879.

Lanzone ME (2012) Populismo e nuove forme di partecipazione politica. Il caso del Movimento 5 Stelle. Paper presented at the 2012 SISP Conference, Roma Tre University, 13-15 September.

Lanzone ME (2015) Il Movimento Cinque Stelle: Il popolo di Grillo dal Web al Parlamento. Novi Ligure: Edizioni Epoké.

Lanzone ME and Rombi S (2014) Who Did Participate in the Online Primary Elections of the M5S in Italy? Causes, Features and Effects of the Selection Process. Partecipazione e Conflitto 7(1), 170-191. https://doi.org/10.1285/i20356609v7ilp170.

Lanzone ME and Rombi S (2018) Selecting Candidates Online in Europe: A Comparison Among the Cases of M5S, Podemos and European Green Party. In Cordero G and Coller X (eds), Democratizing Candidate Selection: New Methods, Old Receipts? New York: Springer, pp. 99-121.

M5S (2009) Non-Statuto. https://s3-eu-west-1.amazonaws.com/materiali-bg/Regolamento-Movimento-5Stelle.pdf.

M5S (2017a) Statuto. https://s3-eu-west-1.amazonaws.com/associazionerousseau/documenti/statuto_ MoVimento_2017.pdf.

M5S (2017b) Codice Etico. https://s3-eu-west-1.amazonaws.com/associazionerousseau/documenti/ codice_etico_MoVimento_2017.pdf.

M5S (2018) Regolamento per La Selezione Dei Candidati Del Movimento 5 Stelle Alle Elezioni Politiche Del 4 Marzo 2018 Nei Collegi Plurinominali e Uninominali. https://s3-eu-west-1.amazonaws.com/associazionerousseau/documenti/regolamento_parlamentarie2018.pdf.

Mair P (2013) Ruling the Void. London: Verso.

Marino B, Martocchia Diodati N and Verzichelli L (2018) From Leaders to Personalities? Evidence from an Expert Survey on the Personalisation of Politics in Western Europe (1985-2016). CIRCaP Occasional Papers. Second Series (4).

Marino B, Martocchia Diodati N and Verzichelli L (2020) Personalisation of Politics Expert Survey (PoPES) Data Set.

Martín I (2015) Podemos y otros modelos de partido-movimiento. Revista Española de Sociología 24, $107-114$.

Mikola B (2017) Online Primaries and Intra-Party Democracy: Candidate Selection Processes in Podemos and the Five Star Movement. IDP. Revista de Internet, Derecho y Politica 24, 37-49. http://dx.doi.org/ 10.7238/idp.v0i23.3070.

Mikola B (2019) New Party Organizations and Intra-Party Democracy: A Comparative Analysis of the Five Star Movement and Podemos. PhD dissertation, Central European University.

Mosca L and Tronconi F (2019) Beyond Left and Right: The Eclectic Populism of the Five Star Movement. West European Politics 42(6), 1158-1183. https://doi.org/10.1080/01402382.2019.1596691.

Mudde C and Rovira Kaltwasser C (2013) Exclusionary vs. Inclusionary Populism: Comparing Contemporary Europe and Latin America. Government and Opposition: An International Journal of Comparative Politics 48(2), 147-174. https://doi.org/10.1017/gov.2012.11.

Musella F (2015) Personal Leaders and Party Change: Italy in Comparative Perspective. Italian Political Science Review/Rivista Italiana di Scienza Politica 45(3), 227-247. https://doi.org/10.1017/ipo.2015.19.

Musella F (2018) Political Leaders Beyond Party Politics. Basingstoke: Palgrave Macmillan.

Musso M and Maccaferri M (2018) At the Origins of the Political Discourse of the 5-Star Movement (M5S): Internet, Direct Democracy and the 'Future of the Past'. Internet Histories. Digital Technology, Culture and Society 2(1-2), 98-120. https://doi.org/10.1080/24701475.2018.1457295. 
Nez H (2017) Podemos: The Emergence of a New Political Party in Spain. In Chommeloux A and Gibson-Morgan E (eds), Contemporary Voting in Europe. Patterns and Trends. London: Palgrave, pp. 113-128.

OpenPolis (2018) L'infinito giro di valzer dei cambi di gruppo. 23 February, www.openpolis.it/linfinitogiro-di-valzer-dei-cambi-di-gruppo/.

Pérez-Nievas S et al. (2018) New Wine in Old Bottles? The Selection of Electoral Candidates in General Elections in Podemos. In Cordero G and Coller X (eds), Democratizing Candidate Selection: New Methods, Old Receipts? New York: Springer, pp. 123-146.

Pirro ALP (2018) The Polyvalent Populism of the 5 Star Movement. Journal of Contemporary European Studies 26(4), 443-458. https://doi.org/10.1080/14782804.2018.1519484.

Podemos (2014) Estatutos del partido político PODEMOS. https://participa.podemos.info/pdf/estatutos_ de_podemos.pdf.

Podemos (2015) Elección de los candidatos y candidatas de Podemos a la Presidencie del Gobierno de España, al Congreso de los Diputados y al Senado: Elecciones generales de 2015. https://podemos. info/wp-content/uploads/2015/01/Reglamento-primarias-para-las-generales.pdf.

Podemos (2017a) Estatutos de PODEMOS. https://files.podemos.info/XQpfxDwEvT.pdf.

Podemos (2017b) Documento Organizativo PODEMOS. https://files.podemos.info/9AMl3us6iC.pdf.

Rahat G and Hazan RY (2001) Candidate Selection Methods: An Analytical Framework. Party Politics 7(3), 297-322. https://doi.org/10.1177/1354068801007003003.

Rahat G and Shapira A (2017) An Intra-Party Democracy Index: Theory, Design and A Demonstration. Parliamentary Affairs 70(1), 84-110. https://doi.org/10.1093/pa/gsv068.

Rahat G and Kenig O (2018) From Party Politics to Personalized Politics? Oxford: Oxford University Press.

La Repubblica (2014) M5s, i militanti dicono sì: nasce il direttorio a Cinque stelle. Grillo: 'Costruiamo il futuro'. 28 November, www.repubblica.it/politica/2014/11/28/news/grillo_stanchino-101618825.

Roodujin M, Van Kessel S, Froio C, Pirro A, De Lange S, Halikiopoulou D, Lewis P, Mudde C and Taggart P (2019) The PopuList: An Overview of Populist, Far Right, Far Left and Eurosceptic Parties in Europe. www.popu-list.org.

Schattschneider EE (1942) Party Government. New York: Rinehart and Company.

Seddone A and Rombi S (2018) The Selection of Candidates and Its Impact on Parliamentary Behaviour: Insights from the Italian Case. In Cordero G and Coller X (eds), Democratizing Candidate Selection. Basingstoke: Palgrave Macmillan, pp. 231-253.

Sola J and Rendueles C (2017) Podemos, the Upheaval of Spanish Politics and the Challenge of Populism. Journal of Contemporary European Studies 26(1), 99-116. https://doi.org/10.1080/14782804.2017. 1304899.

Tronconi F (ed.) (2015) Beppe Grillo's Five Star Movement. Burlington: Ashgate.

Tronconi F (2018) The Italian Five Star Movement During the Crisis: Towards Normalisation? South European Society and Politics 23(1), 163-180. https://doi.org/10.1080/13608746.2018.1428889.

Van Biezen I and Poguntke T (2014) The Decline of Membership-Based Politics. Party Politics 20(2), 205216. https://doi.org/10.1177/1354068813519969.

Vignati R (2015a) Beppe Grillo and the Movimento 5 Stelle: A Brief History of a 'Leaderist' Movement with a Leaderless Ideology. In Tronconi F (ed.), Beppe Grillo's Five Star Movement: Organisation, Communication and Ideology. Farnham: Ashgate, pp. 9-28.

Vignati R (2015b) The Organization of the Movimento Cinque Stelle: A Contradictory Party Model. In Tronconi F (ed.), Beppe Grillo's Five Star Movement: Organisation, Communication and Ideology. Farnham: Ashgate, pp. 29-52.

Vittori D (2017) Podemos and the Five Stars Movement: Divergent Trajectories in a Similar Crisis. Constellations 24, 324-338. https://doi.org/10.1111/1467-8675.12291.

Vittori D (2019) The Impact of Populism on Party Organization? A Study of Four Southern European 'Populist' Parties. European Politics and Society. https://doi.org/10.1080/23745118.2019. 1602925.

Vittori D (2020) Five Stars Movement Internal Consultations (2012-2019). Version: 1.0.0. GESIS Datenarchiv. Data set. https://doi.org/10.7802/1.1986. 
Wauters B, Thijssen P and van Aelst P (2016) Centralized Personalization at the Expense of Decentralized Personalization: The Decline of Preferential Voting in Belgium (2003-2014). Party Politics 24(5), 511523. https://doi.org/10.1177/1354068816678882.

Zulianello M (2020) Varieties of Populist Parties and Party Systems in Europe: From State-of-the-Art to the Application of a Novel Classification Scheme to 66 Parties in 33 Countries. Government and Opposition: An International Journal of Comparative Politics 55(2), 327-347. https:/doi.org/10.1017/ gov.2019.21.

Cite this article: Caiani M, Padoan E, Marino B (2022). Candidate Selection, Personalization and Different Logics of Centralization in New Southern European Populism: The Cases of Podemos and the M5S. Government and Opposition: An International Journal of Comparative Politics 57, 404-427. https:// doi.org/10.1017/gov.2021.9 